L.N. Walker, J.E. Mylroie, A.D. Walker, and J.R. Mylroie - Symmetrical cone-shaped hills, Abaco Island, Bahamas: karst or pseudokarst? Journal of Cave and Karst Studies, v. 72, no. 3, p. 137-149. DOI: 10.4311/jcks2009es0100

\title{
SYMMETRICAL CONE-SHAPED HILLS, ABACO ISLAND, BAHAMAS: KARST OR PSEUDOKARST?
}

\author{
Lindsay N. Walker ${ }^{1}$, John E. Mylroie²*, Adam D. Walker ${ }^{1}$, and Joan R. Mylroie ${ }^{2}$
}

\begin{abstract}
Abaco Island, Bahamas, contains a large number of conical hills that strongly resemble cone karst, a dissolutional landform associated with karst processes in tropical carbonate localities around the world. Field investigation demonstrated that the conical hills are roughly symmetrical in shape and consist of mid to late Pleistocene eolian calcarenites (carbonate sand dunes) partly mantled by talus. The original hummocky depositional topography of the eolian ridges has been dissected by a variety of processes including dissolution pit formation that enhances slope failure, vegetative disruption of the rock surface, and fire-induced exfoliation of the bedrock. The original asymmetrical shape of continuous dune ridges has thus been modified into a series of hills with a symmetrical cone shape, in which the steeper leeward depositional slopes of the dunes have been masked by talus to create a lesser slope that approximates the dip of the exposed bedrock slope of the more gentle windward depositional faces of the dunes. The conical hills are primarily constructional in nature, modified by mass-wasting slope processes only partly influenced by dissolution; therefore these conical hills are not true cone karst, but pseudokarst, despite their cone shape and their development in soluble carbonate rock. Abaco is the only island in the Bahamian Archipelago with both high eolian relief and a significant positive water budget; that water budget supports the degree of dissolution and forest growth necessary to create the root wedging and fireinduced exfoliation that most modify the steep leeward slopes of the dunes. As the eolian calcarenites were deposited only during the brief glacioeustatic sea-level highstands of the last few hundred thousand years, the development of cone-shaped hills in these eogenetic rocks has been geologically very rapid.
\end{abstract}

\section{INTRODUCTION}

The presence of residual limestone hills is well documented in tropical localities around the world (Ford and Williams, 2007 and references therein; Jennings, 1985 and references therein; Lehmann, 1936; Sweeting, 1973 and references therein; Day, 2004 and references therein). Some of the best known localities are China, Malaysia, Vietnam, Jamaica, New Guinea, Java, Puerto Rico, Cuba, and the Philippines. These landscapes may be referred to as tower karst. Ford and Williams (2007, p. 371), state: "The word 'tower' therefore subsumes a myriad of forms, and a variety of terms in different languages has been used to describe them, including turm, mogote, cone, piton, hum and pepino." Cone karst (or kegelkarst) refers specifically to cone-shaped hills produced by karst processes (Day, 2004). Cone karst is considered by most karst scientists as a subdivision of tower karst, and these two karst landforms often exist in close proximity to one another (Ford and Williams, 2007).

The presence of such landforms has been attributed to incision of a thick limestone plateau by stream action as the landscape adjusts to a new, lower base level, leaving residual hills of cone or tower shape (Ford and Williams, 1989; 2007; Tang and Day, 2000). Changing base levels are often preserved within the landscape as terraces and abandoned caves exposed in the residual hills, which indicates that tower-karst development is typically a prolonged process (Gillieson, 1996; White, 1988). Residual hills can also form due to high-density development of karst depressions, called dolines or cockpits (Haryono and Day, 2004; Sweeting, 1973; Trudgill, 1985; Versey, 1972; White 1988; 1990; Williams, 1972). Cockpit is the preferred term in some regions of tropical karst, while doline is more commonly used in temperate climates. Adjustment to baselevel lowering results in depression development downward at a rate comparable to depression widening, leaving residual hills at the intersections of the depressions (White, 1988). Tropical karst areas where depressions dominate are often referred to as cockpit karst (Sweeting, 1973) or polygonal karst (Williams, 1972).

Residual limestone hills may also form from corrosion of the surrounding landscape, in which denudation takes place almost entirely by subaerial dissolution (Ford and Williams, 1989). Lowering of the surface continues until base level is reached. This landscape lowering implies a large amount of subaerial dissolution with minimal contribution by mechanical processes over a long period of time.

\footnotetext{
*Corresponding Author, mylroie@geosci.msstate.edu

${ }^{1} 60200$ Glacier Drive, Canmore, AB T1W 1K6, Canada, s03.lmccullough@ wittenberg.edu

${ }^{2}$ Department of Geosciences, Mississippi State University, Mississippi State, MS 39762 USA
} 


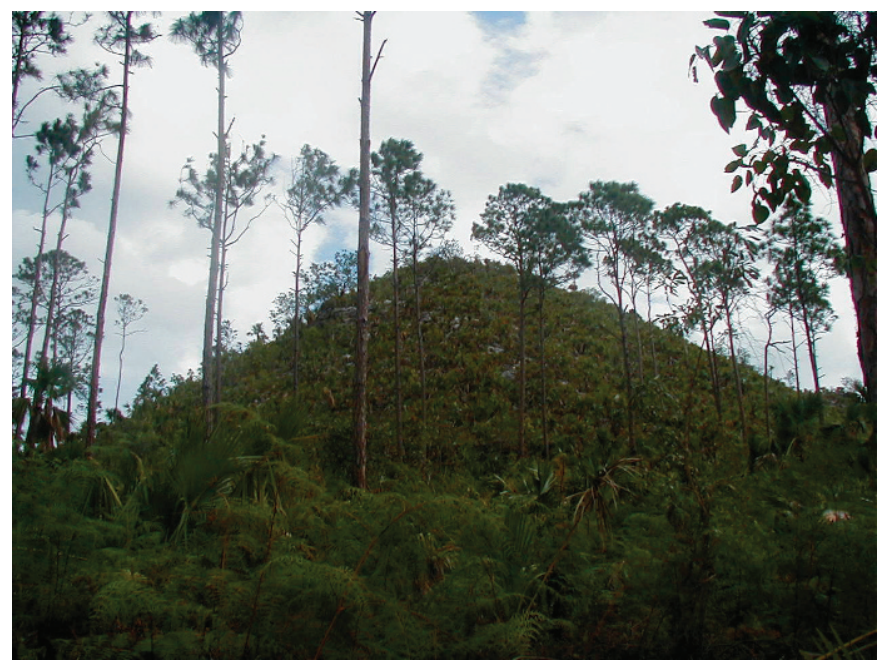

Figure 1. Symmetrical cone-shaped hill E on Abaco, along the N-S profile of the ridge. This cone is approximately $22 \mathrm{~m}$ in height. The photographer is facing east, with north to the left of the photograph and south to the right.

Though cone and tower karst are well documented on the limestone terrains of many islands (Haryono and Day, 2004; Lehmann, 1936; Sweeting, 1973; Versey, 1972; Williams, 1972), they have never been described in the Bahamas. These island tower karst settings fall into the category of karst on islands, as opposed to island karst (Vacher and Mylroie, 2002). Karst on islands does not differ from that found in continental settings, while island karst is influenced by sea-level position and marine or fresh water geochemistry. In other words, the island setting is not critical to the development of tower karst.

The purpose of this study is to document and describe the morphology of landforms on Abaco Island, Bahamas, that bear a striking resemblance to tropical cone karst in order to understand their formation (Figs. 1 and 2). The shape of the residual hills on Abaco is most similar to cone karst found in Puerto Rico and the Philippines, which is why the landforms on Abaco will be referred to as coneshaped hills; they are certainly not towers. Cone-shaped hills on limestones that display a variety of other karst features (karren, caves, pits, etc.), as do the hills on Abaco, lead the casual observer to assume the hills are cone karst. The presence of cone-shaped landforms on Abaco is particularly interesting because Abaco lacks many of the features and processes that have been attributed to cone karst formation in other localities, such as surface streams and interlocking karst depressions. In addition, the eogenetic limestones that comprise the surficial geology of Abaco are too young in age (mid to late Pleistocene) for uplift and corrosion to be solely responsible for landscape denudation, implying that other processes are at work. Are the cone-shaped hills of Abaco Island true cone karst, or pseudokarst?

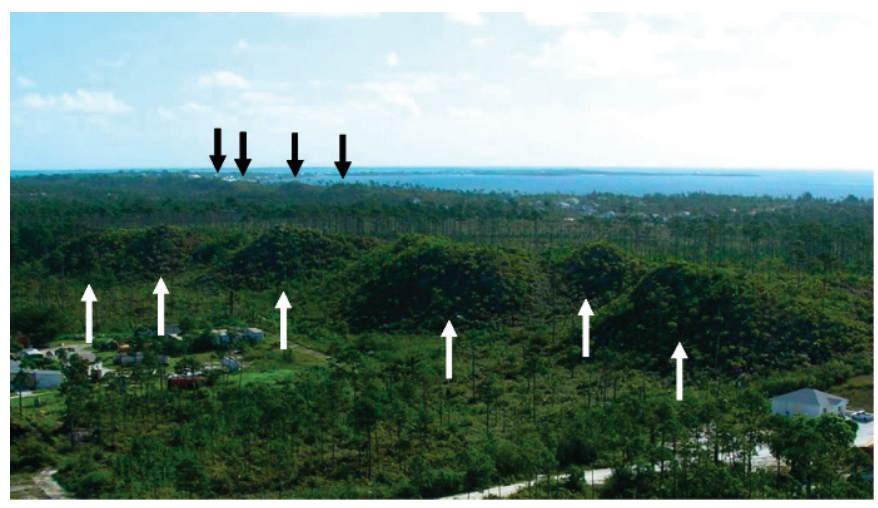

Figure 2. Areal view of Abaco cone-shaped hills; note how the overview reveals aspects of asymmetry of the hills not obvious from the ground view of Figure 1. White arrows identify foreground hills, black arrows hills in the distance.

\section{Study Area}

The Commonwealth of the Bahamas forms a NW-SEtrending archipelago of thick carbonate banks located southeast of Florida and northeast of Cuba (Fig. 3). Abaco Island, located on Little Bahama Bank at the northern end of the archipelago, is the eastern-most island on the bank, which itself is the northernmost bank in the archipelago (Figs. 3 and 4A). Abaco is bordered on the east by the deep waters of the Atlantic Ocean, on the south by the deep waters of the NW Providence Channel and the NE Providence Channel, and on the west by the shallow waters of the Little Bahama Bank (Fig. 3). The landmass of Abaco consists of two main islands, Great Abaco Island and Little Abaco Island, and numerous outlying cays (Fig. 4A).

Cone-shaped landforms occur in many separate localities on Abaco, but are particularly concentrated on the eastern side of Great Abaco Island south of Marsh Harbour. The work for this study was conducted at a site approximately $10 \mathrm{~km}$ south of Marsh Harbour (Fig. 4). The geology of the area consists dominantly of Pleistocene eolianite ridges and interdune areas that are locally covered by a patchy terra rossa paleosol (Walker et al., 2008a). The paleosol has been largely removed from the land surface by denudation and only remains in cracks and solution pits. The entire land surface of the study area, including both the eolianite ridges and the surrounding lows, has been highly weathered and modified by karst processes resulting in a high density of dissolution pits, extensive karren development, and the presence of a hard calcrete layer on exposed limestone bedrock (Walker et al., 2008a; 2008b). The vegetation in the study area is dominated by Caribbean pines (Pinus caribae) and abundant low scrub vegetation (Fig. 5); this vegetation pattern was later understood to be of great importance. The low areas surrounding the ridges are covered by a veneer of loose rock (Fig. 6). In discussions with other workers on Abaco, 


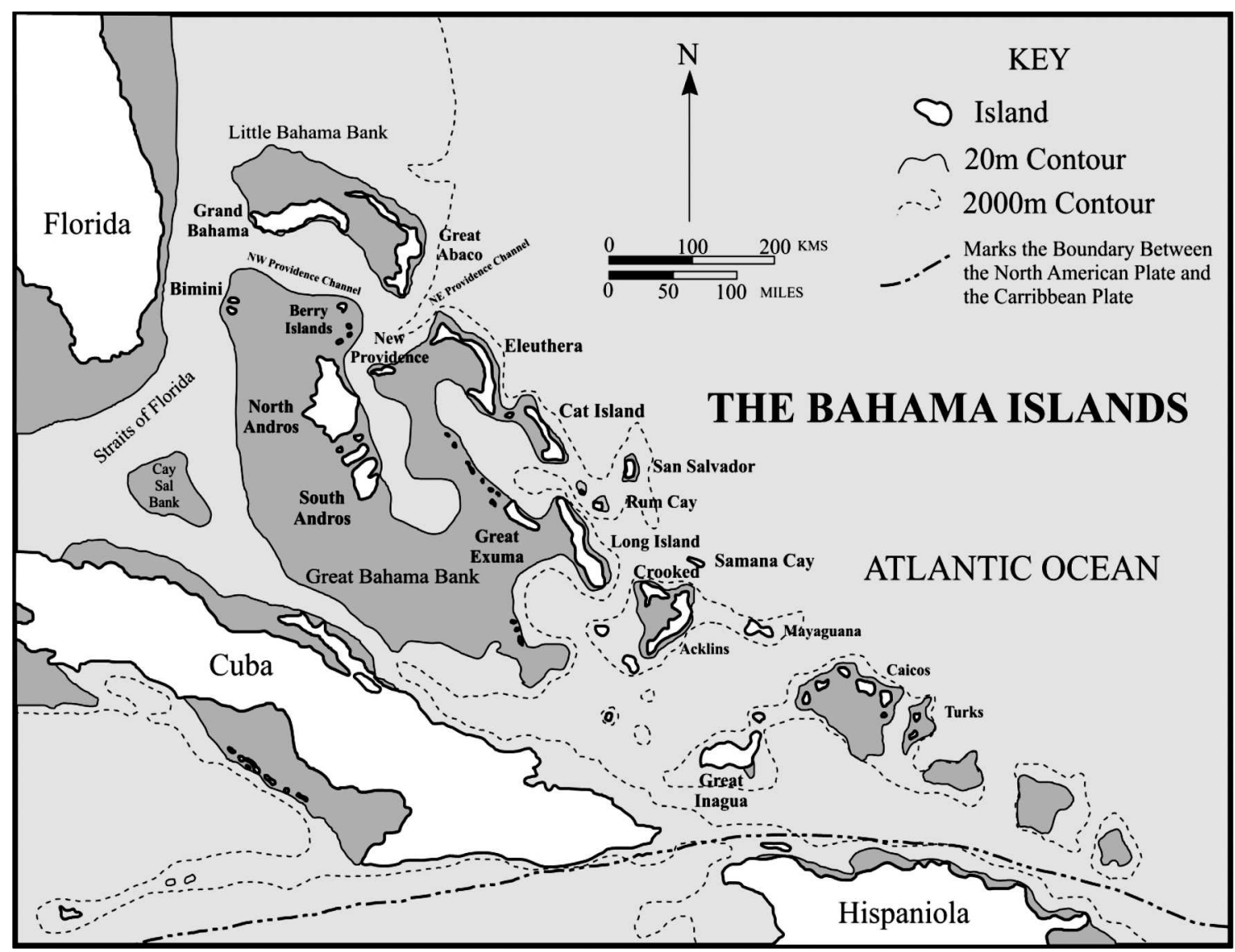

Figure 3. Map of the Commonwealth of the Bahamas (modified from Carew and Mylroie, 1995).

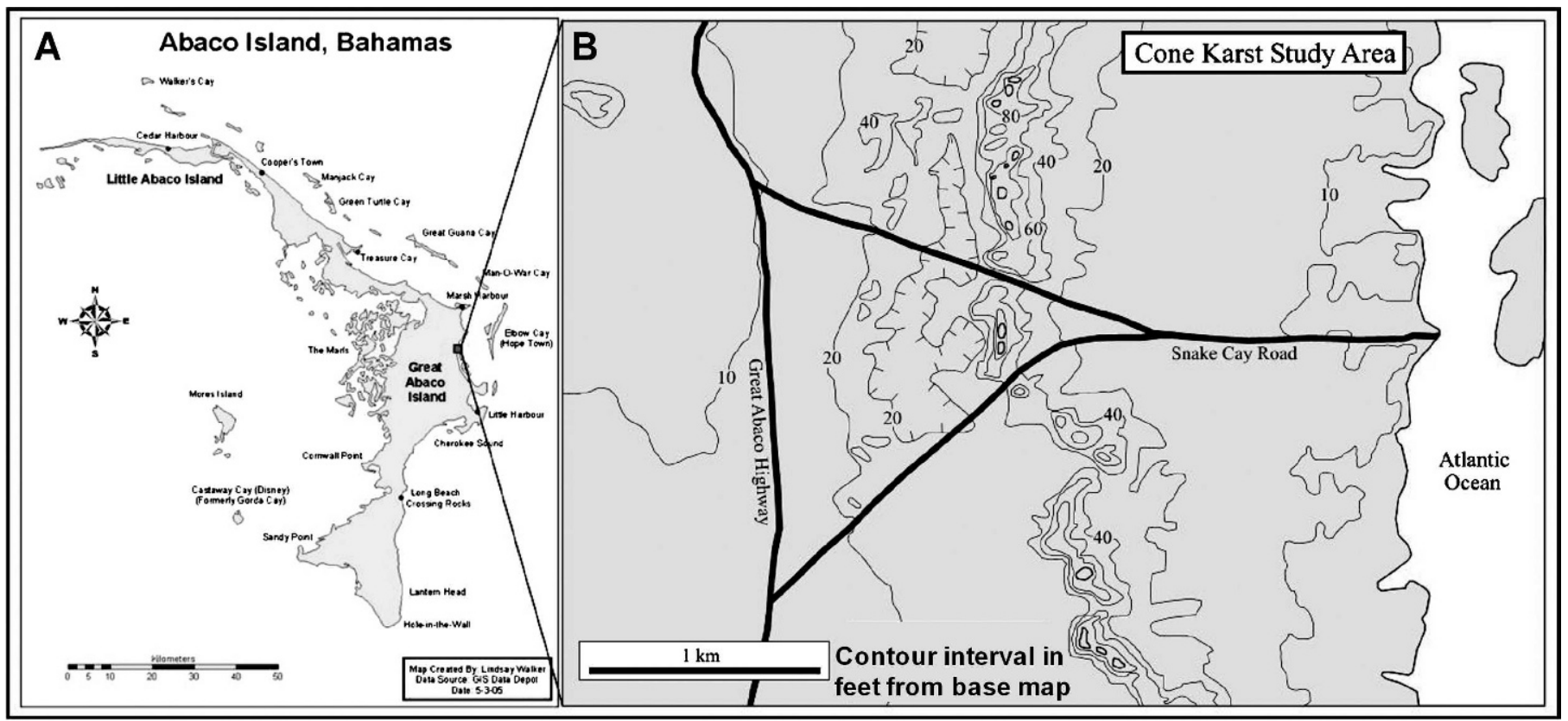

Figure 4. (A) Map of Abaco Islands, Bahamas, showing the location of the cone study area. (B) Topographic map of the cone study area showing the presence of individual isolated hills within a larger eolianite dune ridge (modified from Department of Lands and Surveys, 1975). 


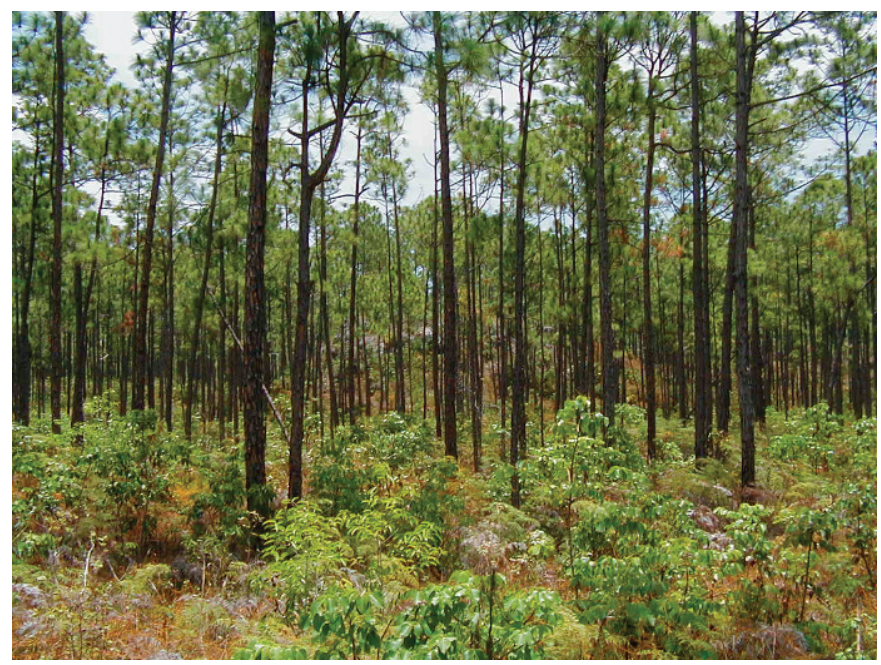

Figure 5. General view of the vegetation of Abaco, dominated by the Caribbean pine (Pinus caribae). A small coneshaped hill is barely visible in the background.

this surface has been referred to descriptively as felsenmeer (sea of stones, without any implications of arctic or alpine origin). On the low areas surrounding the ridges, this weathered rock cannot be mechanically transported and becomes part of a stony soil profile on an epikarst surface.

Eolian calcarenites, or carbonates dunes (commonly referred to as eolianites), form all high ground in the Bahamas above $8 \mathrm{~m}$ elevation, and can reach elevations over $60 \mathrm{~m}$ (Carew and Mylroie, 1997; 2001). They contain an internal architecture produced by eolian processes that controls their overall morphology. Classic studies of Bahamian eolianites by White and Curran (1985), Curran and White (2001), and Caputo (1995) provide detailed descriptions of Holocene and Pleistocene dune suites, respectively. Comparison with ancient carbonate dune suites is provided by Carew and Mylroie (2001). Simplifying from those studies, the dunes form transverse to the prevailing wind direction as hummocky, lobate ridges, with gentle slopes on the windward side and steeper slopes of the leeward side. The gentle windward sides consist of climbing-translatent stratifications (Loucks and Ward, 2001), also called wind-ripple laminations (Curran and White, 2001), that are deposited upslope in the downwind direction. This downwind, but uphill, layering can account for the majority of the stratification in carbonate dunes (Loucks and Ward, 2001). The leeward sides of the dunes are steeper, associated with grainfall and sand-flow units that commonly produce foreset beds that dip steeply in the downwind direction.

\section{Methods}

In order to understand the formation of the cone landforms on Abaco, it was necessary to quantify their shape and size. Dimensions of the cone-shaped landforms

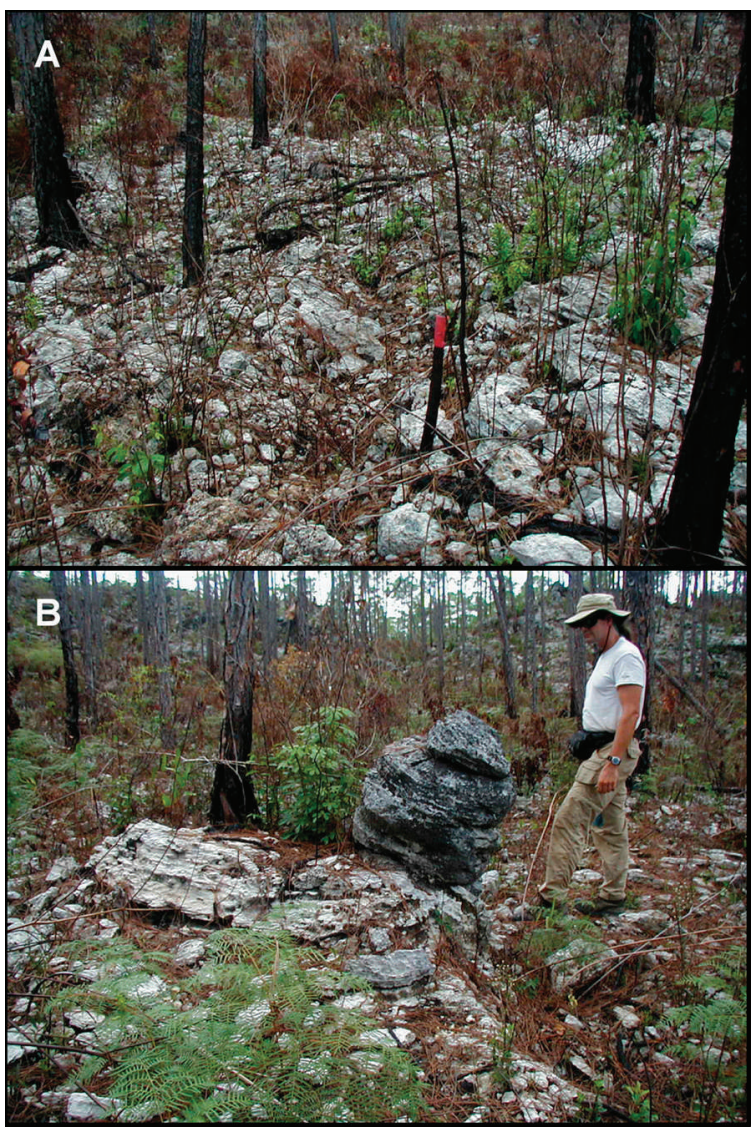

Figure 6. The felsenmeer surface in the cone study area. (A) Rock surface covered by loose blocks, machete in centerforeground 1-m long for scale. (B) Larger blocks typically found between the conical hills.

were determined by making basic height and slope measurements of 31 cone-shaped hills (labeled A-EE in the tables), paying special attention to identifying the extent of their symmetry. Heights were measured using a Suunto inclinometer and tape measure. Slope angles were measured in all four cardinal directions, also using a Suunto inclinometer. Slope measurements were not taken in locations where a cone-shaped hill had been artificially cliffed, such as road cuts. The orientation and dip of preserved stratification were noted to relate the primary dune structure to the resulting hill shape. Cone-shaped hills were classified as belonging either to the large main eolianite ridge or to smaller spur ridges oblique to the main ridge in the study area (Fig. 4B). Field observations as to the location and density of dissolution pits and other possible erosional mechanisms were also documented.

\section{RESULTS}

The cone-shaped landforms are approximately symmetrical in shape, and are formed from the dissection and modification of Pleistocene eolianite ridges (Figs. 2 and 


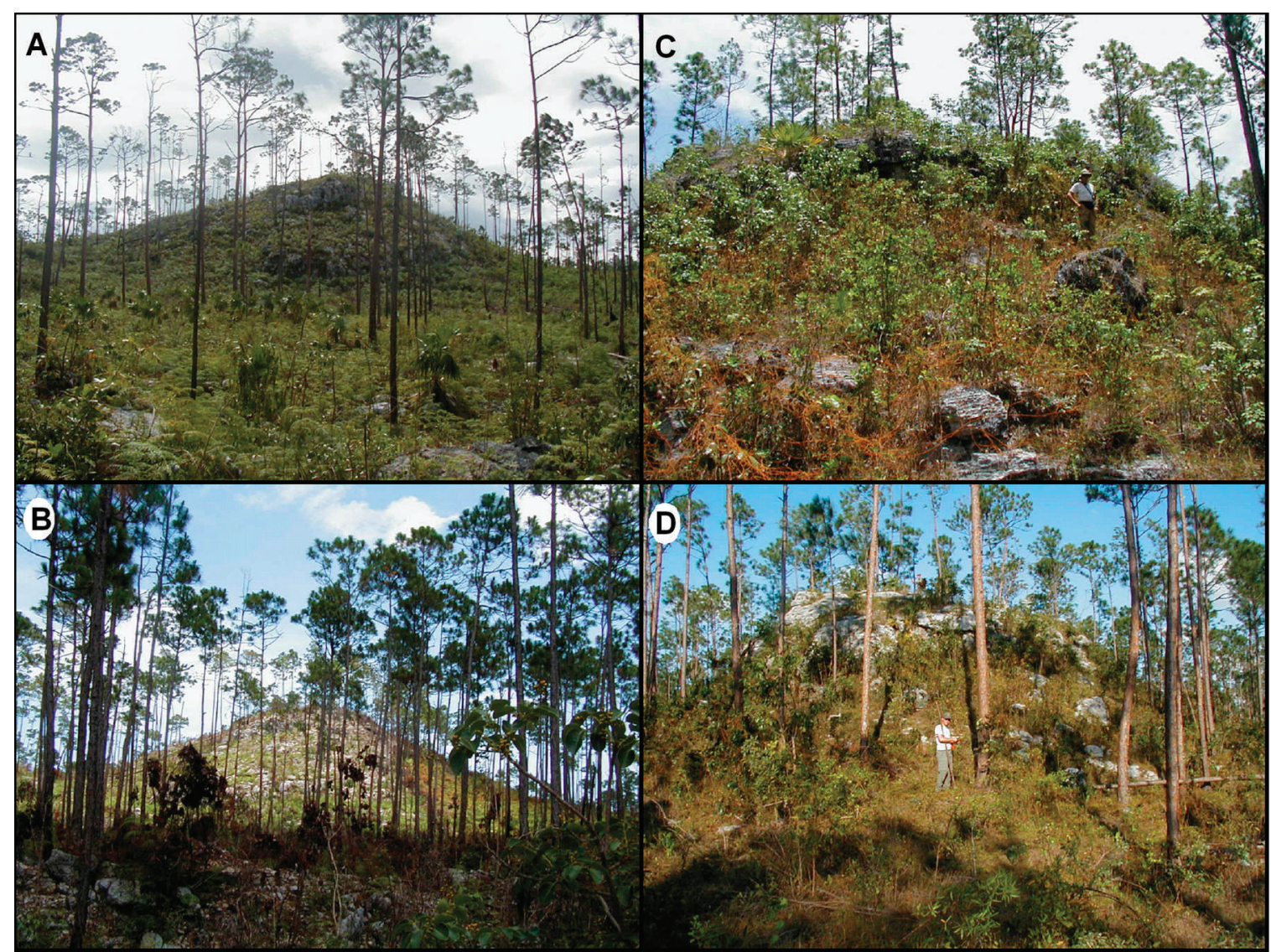

Figure 7. The shapes of typical cone-karst landforms in the study area. (A) Cone-shaped landform $\mathbf{J}$ showing some residual asymmetry along the E-W profile of the main ridge as a result of the originally asymmetrical eolianite depositional pattern. This cone is approximately $19 \mathrm{~m}$ in height. The photographer is facing south, with the east, or gentler windward side, on the left of the photograph and the west, or steeper leeward side, on the right. (B) Cone-shaped landform I showing the symmetrical shape along the E-W profile of the main ridge. This cone is approximately $21 \mathrm{~m}$ in height. The photographer is facing south, with east on the left of the photograph and west on the right. (C) Small cone-shaped hill, showing an apron of talus in the foreground. (D) Small cone-shaped hill with talus to the right of the figure.

4B). The east slope of the hill follows the dip of the windward, translatent or wind-ripple bed stratification of the dune, while the other slopes are formed by truncation of tranlatent or wind-ripple beds and production of talus slopes to form a nearly symmetrical cone (Figs. 1, 2 and 7). Cone-karst landforms in other localities, such as China, have also been known to cut across geologic structure, suggesting that the conical form is more dependent on weathering processes than structural controls (Ford and Williams, 2007). In some cases, the Abaco cone-shaped hills may preserve some of the asymmetry of the original dune ridge (Figs. 2 and 7A).

The cone-shaped hills range in height from 2 to $22 \mathrm{~m}$ above the surrounding land surface, with a mean height for all cones of $11.2 \mathrm{~m}$ (Tables 1 and 2). The east slopes of the cone-shaped hills were usually the gentlest, with a mean slope of $13.6^{\circ}$ (Tables 1 and 2). The west slopes were generally the steepest, with a mean slope of $25.0^{\circ}$ (Tables 1 and 2 and Fig. 7A). The north and south slopes had similar means of 20.9 and 21.0 respectively (Tables 1 and 2 and Fig. 7B).

The cone-shaped hills can be divided into two populations. The first population consists of 19 coneshaped hills dissected from a large, main ridge that trends generally N-S, and the second population consists of 12 cone-shaped hills dissected from smaller spur ridges oblique to the main ridge, trending NE to SW. Coneshaped hills formed from the main ridge are generally larger, with a mean height of $14.0 \mathrm{~m}$ (Table 1), while those from the spur population are smaller, with a mean height of $6.7 \mathrm{~m}$ (Table 2). The main-ridge cone-shaped hills have slopes that are always steepest on the west and gentlest on the east (Table 1 and Figs. 2 and 7A). The spur-ridge cones have slopes that are, on average, gentlest on the east, but do not show a side that is consistently steeper based on the slope measurements taken (Table 2 and Fig. 7D).

Main-ridge cone-shaped hills show foreset beds dipping to the west (leeward) and gentler translatent or wind-ripple 
Table 1. Main ridge cones.

\begin{tabular}{lccccc}
\hline Cone & Height $(\mathrm{m})$ & N Slope $\left(^{\circ}\right)$ & S Slope $\left(^{\circ}\right)$ & E Slope $\left(^{\circ}\right)$ & W Slope $\left(^{\circ}\right)$ \\
\hline $\mathrm{D}$ & 6.1 & 30.0 & 24.0 & 15.0 & 34.0 \\
$\mathrm{E}$ & 22.0 & 29.0 & 26.0 & 17.0 & 30.0 \\
$\mathrm{~F}$ & 18.4 & N/A & N/A & 14.0 & 29.0 \\
$\mathrm{G}$ & 15.7 & N/A & 22.0 & 14.5 & 30.0 \\
$\mathrm{H}$ & 13.8 & 16.0 & 26.0 & 13.0 & 32.0 \\
$\mathrm{I}$ & 21.4 & 24.0 & 18.0 & 20.0 & 33.0 \\
$\mathrm{~J}$ & 19.1 & 27.0 & 23.0 & 16.0 & 32.0 \\
$\mathrm{~K}$ & 19.0 & 12.0 & 27.0 & 10.0 & 32.0 \\
$\mathrm{~L}$ & 6.0 & 14.0 & 15.0 & 17.0 & 32.0 \\
$\mathrm{M}$ & 14.1 & 30.0 & 12.0 & 13.0 & 33.0 \\
$\mathrm{~N}$ & 17.4 & 29.0 & 31.0 & $\mathrm{~N} / \mathrm{A}$ & 28.0 \\
$\mathrm{O}$ & 15.5 & N/A & 26.0 & 15.0 & 30.0 \\
$\mathrm{P}$ & 9.5 & 22.0 & 19.0 & 10.0 & 21.0 \\
$\mathrm{Q}$ & 12.9 & 26.0 & 24.0 & 11.0 & 29.0 \\
$\mathrm{R}$ & 12.5 & N/A & 24.0 & 11.0 & 28.5 \\
$\mathrm{~W}$ & 12.7 & N/A & 25.0 & 22.0 & 27.0 \\
$\mathrm{X}$ & 18.7 & 12.0 & 21.0 & 10.0 & 26.0 \\
DD & 7.1 & 18.0 & 12.0 & 10.0 & 20.0 \\
EE & 4.1 & 19.0 & 15.0 & 11.0 & 20.0 \\
Mean Values & 14.0 & 22.0 & 21.7 & 13.9 & 28.8 \\
\hline
\end{tabular}

$\mathrm{N} / \mathrm{A}=$ areas where slope data unavailable because of artifical cliffing of the dune.

stratification dipping to the east (windward). The eastfacing slope of the main-ridge cones generally follows the dip of the original translatent or wind-ripple stratification, while the west-facing slopes are not as steep as the original slip-face of the dune due to truncation of the beds and the formation of talus slopes (Fig. 8). Spur-ridge cone-shaped hills show foreset beds dipping generally to the southwest. The current southwest slope of the cone is not as steep as the original slip-face of the dune, again due to truncation of the beds and the formation of talus slopes. The northeast slopes of the spur-ridge cones follow the dip of the original translatent or wind-ripple stratification of the dune ridge.

Field observations show that dissolution pits are commonly found in lines along the flanks of the coneshaped landforms (Fig. 9). These lines of dissolution pits are often coexistent with small-scale breaks in slope that allow for the collection of run-off during high-intensity rainfall events and thus increased dissolution. In addition, forest fires, which occur frequently in the pine forests of Abaco, cause cracking and exfoliation of the bedrock (Fig. 10A-B). Another common erosional mechanism in

Table 2. Spur ridge cones.

\begin{tabular}{lccccc}
\hline Cone & Height $(\mathrm{m})$ & N Slope $\left(^{\circ}\right)$ & S Slope $\left(^{\circ}\right)$ & E Slope $\left(^{\circ}\right)$ & W Slope $\left(^{\circ}\right)$ \\
\hline A & 8.2 & 31.0 & 32.0 & 11.0 & 29.0 \\
B & 5.8 & 17.0 & 22.0 & N/A & 27.0 \\
C & 7.2 & 19.0 & 30.0 & 8.0 & 21.0 \\
S & 7.5 & 13.0 & 10.0 & 29.0 & 25.0 \\
T & 10.0 & 15.0 & 23.0 & 10.0 & 29.0 \\
U & 9.9 & 39.0 & 8.0 & 19.0 & 26.0 \\
V & 10.6 & 32.0 & 11.0 & 9.0 & 18.0 \\
Y & 3.6 & 16.0 & 15.0 & 14.0 & 10.0 \\
Z & 3.4 & 13.0 & 9.0 & 10.0 & 11.0 \\
AA & 7.6 & 21.0 & 35.0 & 10.0 & 10.0 \\
BB & 5.0 & 9.0 & 24.0 & 15.0 & 16.0 \\
CC & 2.1 & 11.0 & 20.0 & 9.0 & 19.2 \\
Mean Values & 6.7 & 19.7 & 19.9 & 13.1 & \\
\hline
\end{tabular}

N/A $=$ areas where slope data unavailable because of artificial cliffing of the dune. 


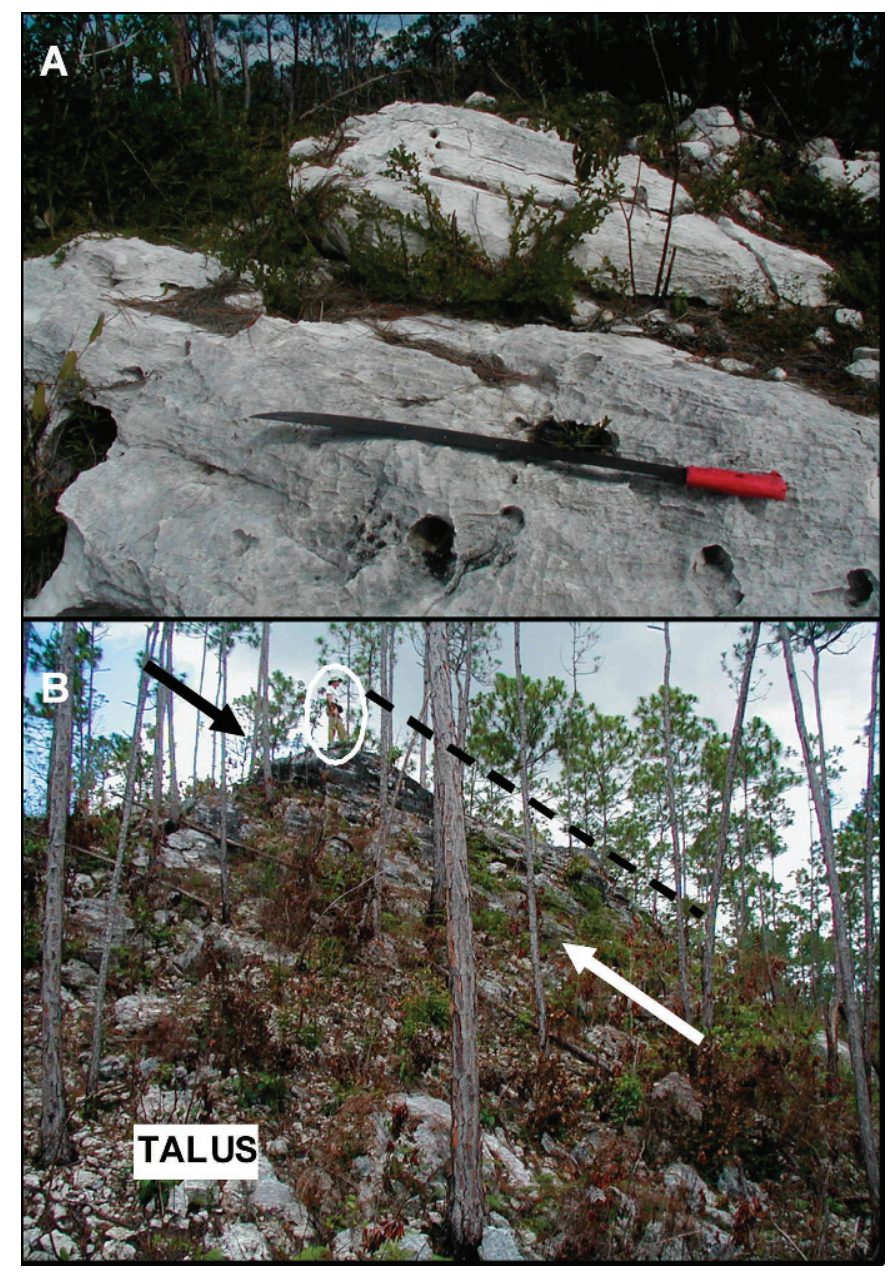

Figure 8. Initial depositional configuration of the coneshaped hills, and subsequent alteration. (A) Outcrop on a hill crest, showing dip to the right, slightly steeper than the 1m-long machete for scale. Note to the left that the dipping translatent or wind-ripple beds are truncated. (B) Coneshaped hill, dip of the eolian beds shown by the black and white arrows. To the right, the hill slope is mostly bare rock following the windward shallow dip (dashed line) of the translatent or wind ripple stratification; to the left, talus has collected to lessen the steeper lee side dip. Person in white oval for scale.

the study area occurs from the disruption of the bedrock surface by the roots of vegetation, particularly pine trees (Fig. 10C-D).

\section{DisCUSSION}

Cone-karst landscapes in the world are formed by processes such as incision of a thick limestone plateau by stream action, lowering of the surface by doline or cockpit development, and corrosion of the surrounding landscape, leaving residual hills. Abaco, however, has no surface streams or broad karst depressions (Mylroie, et al. 1995;
Walker et al., 2008a; 2008b), and the rock from which the cones are formed is so young that it is unlikely that corrosion alone could have caused cone-shaped hills to form. In the absence of surface streams, subaerial chemical and physical erosive processes are dominant.

The eolianite ridges from which the cone-shaped hills form are constructional landforms, created by wind transport of carbonate grains in a subaerial environment. As a result, they are subject to subaerial erosion immediately upon deposition. Because the Bahamas are tectonically stable, with only minor subsidence of 1 to $2 \mathrm{~m}$ per 100,000 years (Carew and Mylroie, 1995) and fluvial erosion is not a factor, much of the relief above present sea level and all relief above $8 \mathrm{~m}$, is the result of these constructional eolian processes (Carew and Mylroie, 1997; 2001). This is, overall, a very different depositional and erosional history than the marine limestones of cone-karst landscapes around the world. The deposition of Bahamian eolianite ridges also takes place in geologic time periods (the approximately 10,000 year-long sea-level highstand events of the Quaternary) that are relatively short compared to the deposition time of limestones in other environments (Carew and Mylroie, 1997). Thus, the erosional processes, both chemical and physical, acting on Bahamian limestone landscapes take place on different time scales and in different ways than would otherwise be expected.

One element of these erosion processes is the rapid development of a karst landscape with a high density of dissolution pits. In Bahamian karst areas, dissolution pits act as vadose fast-flow routes through the carbonate bedrock (Mylroie and Carew, 1995; Harris et al, 1995). Dissolution pits in the study area often form in lines along the flanks of the cone-shaped landforms, causing weak zones on the periphery of the landforms as the pits enlarge and coalesce (Fig. 9A). Eventually, the weak zones develop into fissures, allowing degradation of the slopes by rock fall (Fig. 9B).

The land surface is further mobilized by forest-fireinduced exfoliation of the eolianites (Fig. 10A-B) and disruption of the bedrock surface by vegetation (Fig. 10CD). As eolian ridges initiate with high relief, rock loosened by fire, vegetative, and karst processes mass-wastes down slope as talus. Talus slopes, or debris aprons, are common on cone-karst landforms, due to erosion of the steep slopes (Jakucs, 1977; Marker, 1970). As can be seen in Figures $6 \mathrm{~B}, 7 \mathrm{C}$, and $8 \mathrm{~B}$, the talus blocks produced are subangular to rounded and do not interlock well, creating a lower angle of repose than expected, compared to talus from dense, hard telogenetic limestones in continental settings. The advanced degree of weathering of the limestone on Abaco due to these processes has also resulted in the rock-rubble veneer on the low areas surrounding the cones (Fig. 6). Thus, the cones and the surrounding land surface form from a combination of dissolutional and mechanical processes, and the formation 


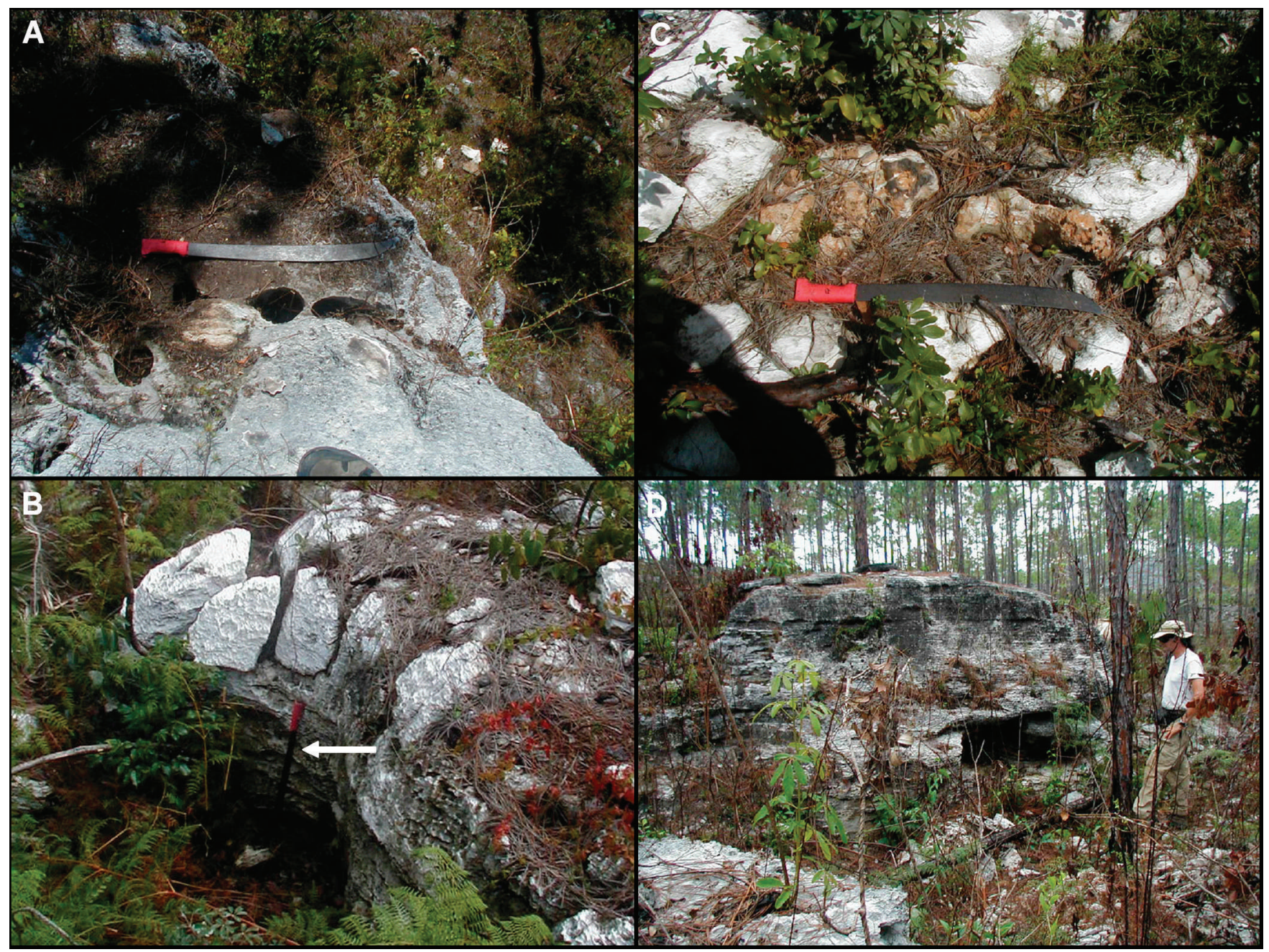

Figure 9. The effects of dissolutional karst processes in the study area (machete 1-m long for scale in A-C). (A) Vertical downward-looking view of dissolution pits forming along the flank of a cone-shaped landform. As these pits enlarge and merge, they will form a weak zone that will eventually fail, causing degradation of the slope. (B) Imminent rock-fall as a result of dissolution-pit formation (machete indicated by the arrow). (C) Terra-rossa paleosol preserved within a dissolution crack (material above and parallel to the machete). Dissolutional denudation has stripped this material from the adjacent flat bedrock surfaces. (D) Small dissolutional cave in a small residual hill.

of the talus slopes causes the originally steep leeward face of the eolianite ridge to become less steep (Fig. 11).

Eolian calcarenites are originally deposited as hummocky ridges, with a predisposition to a cone shape that is subsequently modified by erosion (Fig. 12). A formerly continuous, but asymmetrical, eolian ridge takes on a relatively symmetrical profile (Fig. 13). In the case of the main-ridge cones, this modification takes place along the E-W profile, with the east-facing slope maintaining its original gentle slope, and the west-facing slip or leeward face becoming less steep (Figs. 1 and 8B). In the case of the spur-ridge cones, this modification takes place along the NE-SW profile, with the NE-facing slope maintaining its original gentle slope and the SW-facing leeward face becoming less steep. The remaining asymmetry is often difficult to see under the thick vegetative cover of the study area.

The main ridge cone-shaped hills are predisposed to dissection along the N-S ridge profile due to the original hummocky depositional pattern (Fig. 12) of eolian dune ridges in the Bahamas (White and Curran, 1985). Some residual hummocky topography is still evident in the study area, where cone-shaped hills have not been completely isolated from the ridge, despite the intense weathering processes (Fig. 2). Main ridge cone-shaped hills appear more symmetrical in the N-S direction than the E-W direction because the original dip of the beds is not a factor in those directions (Fig. 7A versus 7B). Instead, the coneshaped hills are dissected from the main ridge by the above described fire, vegetative, and karst processes to form 


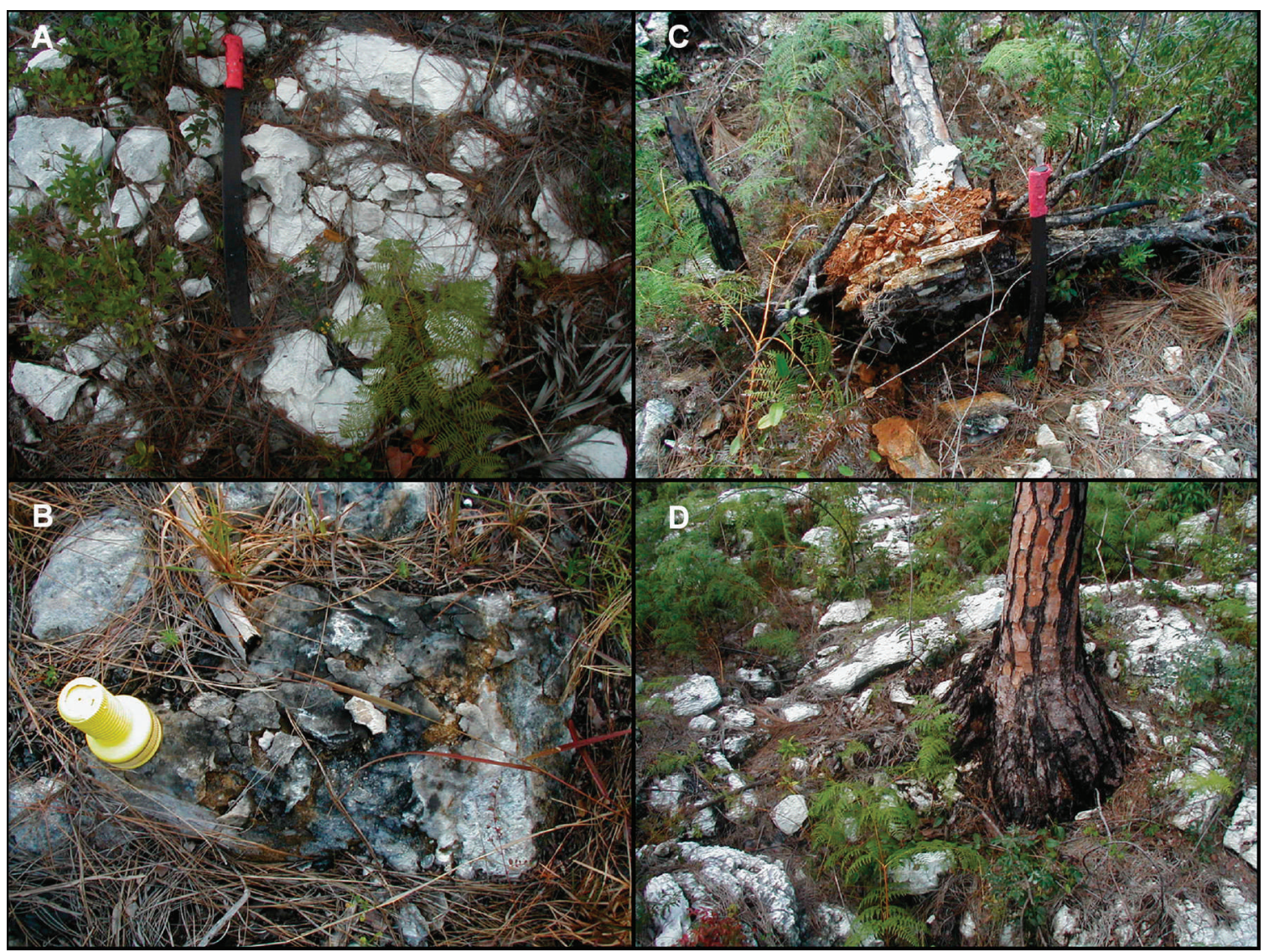

Figure 10. Non-dissolutional erosion mechanisms in the cone study area. (A) Fire-induced exfoliation of the bedrock surface, machete 1-m long for scale. (B) Recent fire exfoliation, rock flakes charred and sooty, flashlight $15 \mathrm{~cm}$ long for scale. (C) Disruption of the bedrock surface in the study area by the roots of pine trees, machete 1-m long for scale. (D) Pine tree bulging out of a dissolution pit, creating strain on the surrounding rock.

relatively symmetrical profiles (Figs. 1, 11 and 13). Again, the cone-shaped hills appear even more symmetrical under the thick vegetative cover of the study area.

The spur ridge cone-shaped hills do not show such an obvious relationship to bed dip and slope as the main ridge cones. This is because the beds of the spur ridge do not dip exactly in the cardinal directions from which the slope measurements were taken. Nevertheless, the relationship

\begin{tabular}{|c|c|}
\hline \\
Original Dune Ridge \\
Mind Direction
\end{tabular}

Figure 11. Modification of an originally asymmetrical eolianite ridge into relatively symmetrical cone-shaped landforms by the formation of talus slopes due to karst, vegetative, and fire processes. This modification takes place along the E-W profile of the main ridge. can still be seen, in that the eastern slopes are usually the gentlest and generally follow the angle of the beds that dip to the east-northeast. The east-northeast beds represent the climbing slope of the dune, the translatent or wind-ripple strata, while the west-southwest foresets represent the steeper slip slope of the leeward side of the dune.

Such cone-shaped hills are not known from other Bahamian islands. Abaco, however, is the only Bahamian island with high eolian relief in a climate that has a significant positive water budget (Fig. 14). Grand Bahama Island to the west of Abaco is also quite wet but lacks significant eolian relief (no elevations above $8 \mathrm{~m}$ ), and so, has no cone-shaped hills. High eolianite ridges are known to the south and east of Abaco, but on islands with significantly dryer climates. These dry islands do not display cone-shaped hills. This observation implicates meteoric water flux as an important factor in formation of the cone shape. Pine forests, which are the major vegetation type in the cone study area (Fig. 5), only grow on islands with sufficient rainfall (O'Brien, 2006). As pine forests provide ample leaf litter for forest fires, Bahamian islands with pine forests have frequent fires, while, 


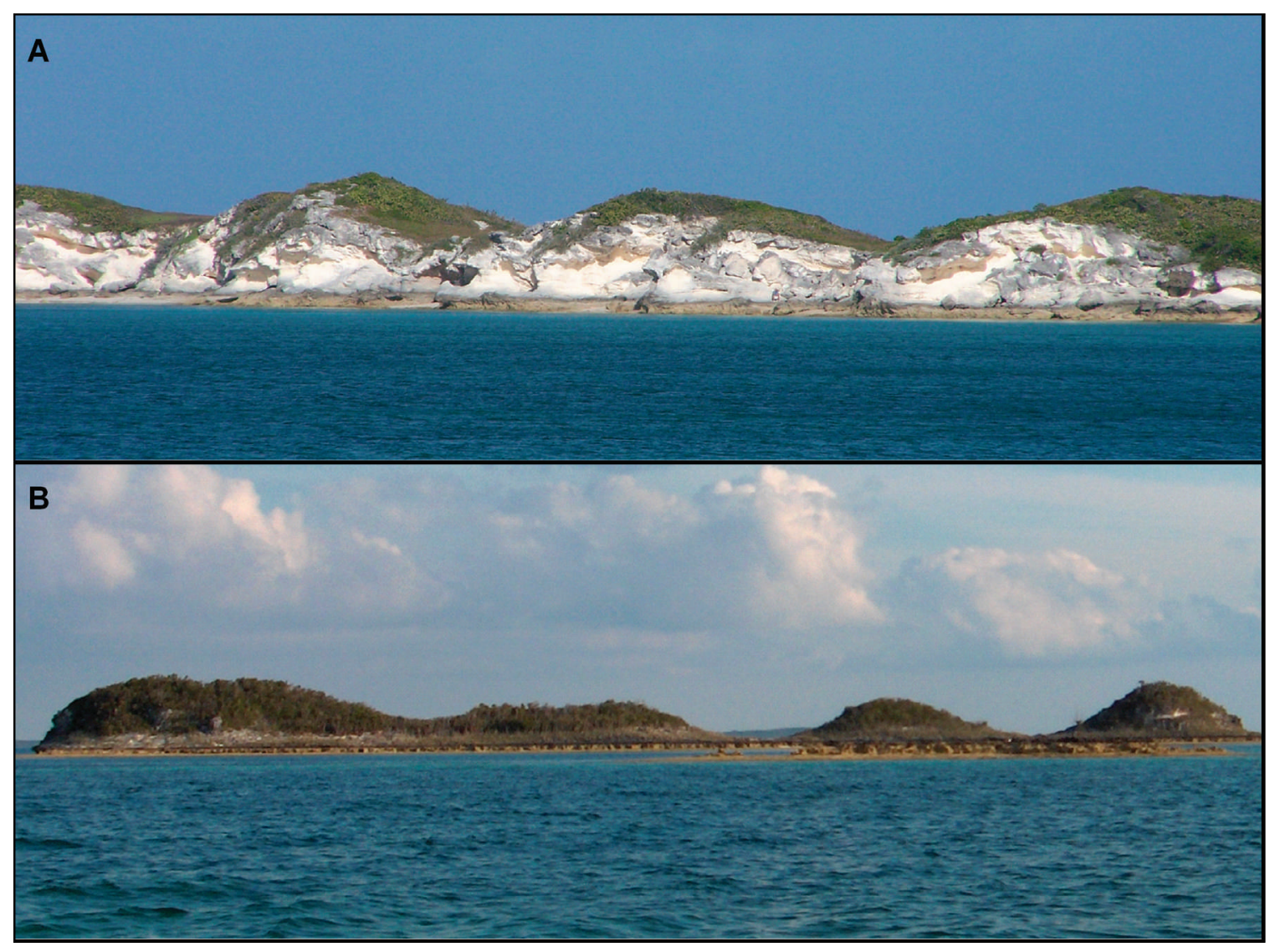

Figure 12. The original depositional topography of Bahamian hummocky dunes can be preserved as dune segmentation by erosion occurs. (A) Holocene North Point Member dunes ( 5000 years old) on San Salvador Island, showing original hummocky topography. (B) Pleistocene dunes on Great Abaco; original hummocky topography, though degraded by erosion, still visible.

somewhat counter-intuitively, drier islands with no pine forests do not have extensive or common fire events (O'Brien, 2006). Thus, the wet climate of Abaco supports the growth of pine forests, which in turn cause forest fires and disruption of the bedrock surface by their roots, and this further contributes to dissection of the eolian ridges into cones and the formation of the rock-rubble surface. The high denudation rate of Abaco relative to other islands in the Bahamas is also evident from the almost complete

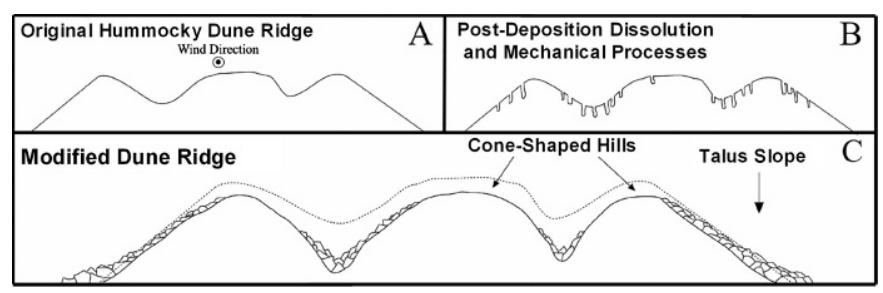

Figure 13. Dissection of an originally hummocky eolianite ridge $(A)$ into cone-shaped landforms $(C)$ by the formation of talus slopes due to karst, vegetative, and fire processes (B). This dissection takes place along the N-S profile of the main ridge. removal of the terra rossa paleosol from the Pleistocene land surface of the study area (Fig. 9C).

The original, asymmetrical structure of the dunes as shown by the depositional strata is in agreement with current prevailing wind directions in the Bahamas. Today, winds in the summer are dominantly from the east and southeast and winds in the winter are dominantly from the northeast (Tucker and Wright, 1990). Assuming the situation was similar in the Pleistocene when the dunes were deposited, the two populations could represent seasonal variations in wind direction (Caputo, 1995; Carew and Mylroie, 1997). The main ridge would represent deposition under a predominent wind direction or the wind direction during times of higher sediment production or transport. The smaller spur ridges would represent deposition under a secondary wind direction or the wind direction at a time of lower sediment production or transport. The two populations could also represent two separate eolianite packages associated with different sealevel highstands. Obtaining proof of either scenario would require large-scale sampling of both ridge populations. At this stage, only preliminary petrographic analysis has been conducted (Walker, 2006). The presence of eolianite ridges 


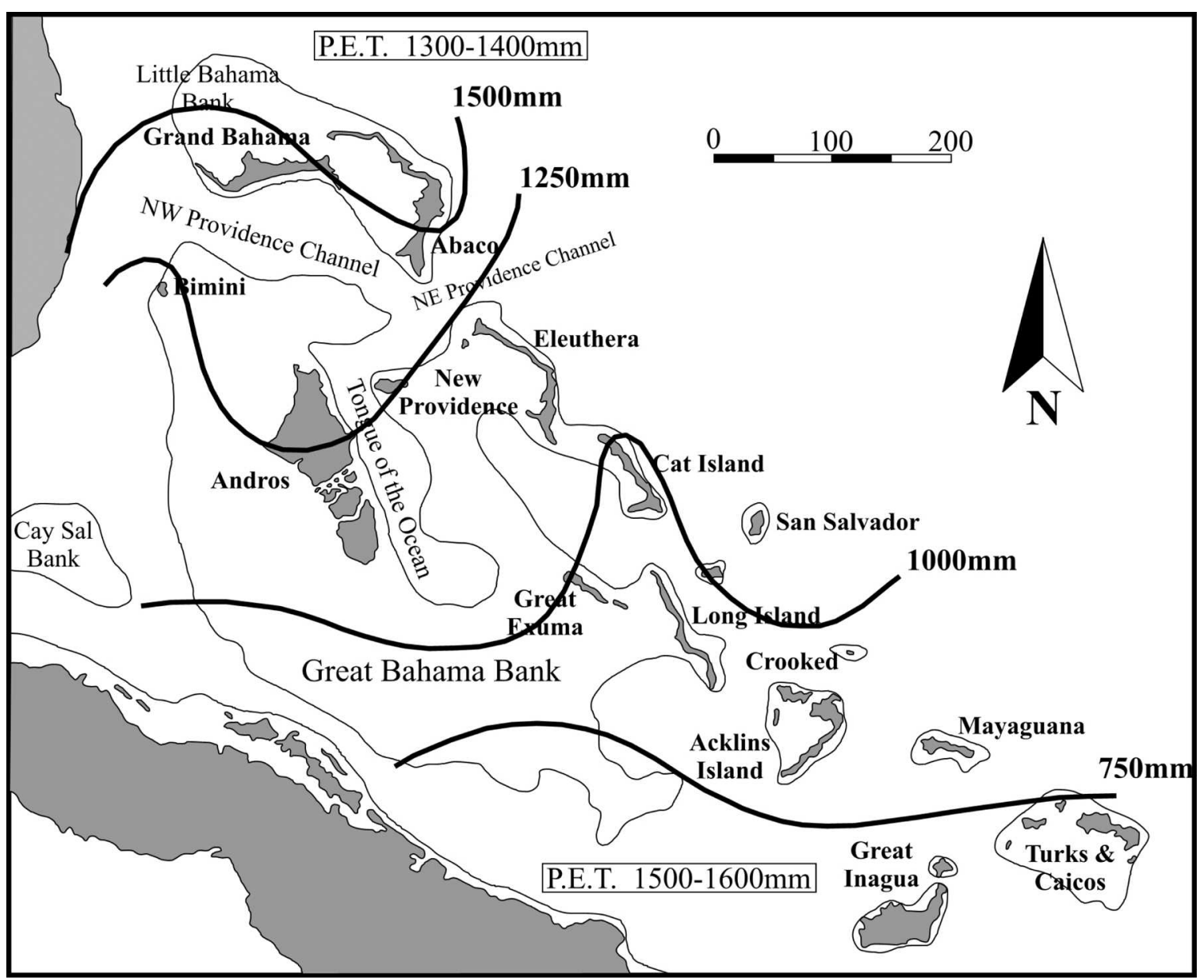

Figure 14. Climate map of the Bahamas showing yearly rainfall (solid contour lines) and P.E.T (Potential Evapotranspiration, in boxes). As shown, Abaco has the largest positive water budget of all the Bahamian islands (modified from Whitaker and Smart, 1997).

in two different orientations is common on other Bahamian islands, such as San Salvador Island (Carew and Mylroie, 1997).

The post-depositional evolution of the porosity of carbonate rocks can be divided into three stages, eogenetic, the time of early burial, mesogenetic, the time of deeper burial, and telogenetic, the stage of erosion of carbonates that have been deeply buried and are now near the surface (Choquette and Pray, 1970). Telogenetic karst is the landscape developed on, and the secondary permeability developed in, ancient rocks that are now exposed after experiencing deep burial (Vacher and Mylroie, 2002). Most traditional forms of karst in continental interiors are formed in telogenetic limestones. Telogenetic rocks are characterized by a low matrix permeability and high fracture and conduit permeability.

Eogenetic karst is a term that refers to the "land surface developing on, and the pore system developing in, young rocks undergoing eogenetic, meteoric diagenesis" (Vacher and Mylroie, 2002, p. 183). The eogenetic rocks of Abaco have a high primary porosity, and consequent high matrix permeability that has not been greatly rearranged. Dissolution pits in eogenetic rocks are not obligated to form along joints and fractures, and so develop in a fashion sensitive to available recharge (Harris, et al., 1995). This situation allows the pits to form on the sides of the eolian ridges without regard to structure and participate in the dissolutional dissection of the ridges. The landforms develop quickly, because mechanical mass-wasting processes interact with dissolutional dissection and modification of the eolianite ridges. Bahamian karst is both syndepositional (caves and karst form while deposition is on-going) and syngenetic (caves and karst form while the carbonates are being consolidated), as reported by Mylroie and Mylroie (2009). Therefore, karst processes were acting on the eolianite ridges starting during the actual formation of the dunes to initiate some of the necessary conditions for weathering and talus accumulation.

It has long been recognized that the characteristic geometries of the residual hills in cone and tower karst landscapes are not solely the result of lithologic and structural controls (Ford and Williams, 2007). Similar 
landforms, for example, have been described in the dense, telogenetic Devonian and Carboniferous limestones of China and in the eogenetic Tertiary limestones of Caribbean islands such as Cuba and Puerto Rico, which have a much higher primary porosity (Ford and Williams, 2007). Does the degree of dissolutional dissection provided by epikarst development and pit cave formation on the eolian ridges of Abaco qualify those cone-shaped hills as cone karst? The initial review of the evidence would suggest not. The cone-shaped hills of Abaco are constructional features modified by a degree of dissolutional dissection coupled with mechanical weathering. The cone shape is derived more from the depositional topography than from the subsequent chemical and mechanical erosion. However, the restriction of these cone-shaped hills to the wettest Bahamian island that also has high-relief dunes argues that the dissolutional component could be critical to the final expression of a cone shape. It could also be argued that the rainfall-sensitive pine-forest vegetation, with its significant root-wedging and forest-fire inducement, causes the mechanical weathering and talus accumulation that is an important component of the final cone shape.

\section{Summary}

The cone-shaped landforms on Abaco represent a unique form of an eogenetic limestone landscape that has not been previously described. The cone-shaped hills form from a combination of dissolutional and mechanical processes as rock loosened by fire, vegetation, and karst processes mass-wastes down slope as talus, acting on a depositional eolian shape predisposed to cone configuration. Thus, formerly asymmetrical eolianite ridges are dissected and modified into relatively symmetrical coneshaped hills. Much of the residual asymmetry is hidden under the thick vegetation of the study area. Cone-shaped landforms have yet to be reported on other Bahamian islands, and none have been seen on the fourteen other Bahamian Islands spanning the entire archipelago visited by the authors. Abaco, however, is most likely the only island in the Bahamas with both the high eolian relief and the large positive water budget necessary for the formation of the landforms.

The cone-shaped landforms on Abaco are obviously in an environment entirely different from that of traditional cone-karst landscapes. The cone-shaped hills on Abaco are not residual remnants resulting from a lowering of the surrounding surface of the land to base level. Their placement above the surrounding landscape is the result of constructional eolian processes. The formation of eolian ridges on carbonate platforms such as the Bahamas is known to take place only during high interglacial sea levels, when flooding of the platform allows for the creation and mobilization of carbonate sediments (Carew and Mylroie, 1997; 2001). Therefore these cone-shaped hills are initially the result of base level rising instead of falling. Erosional modification and dissection initiates immediately upon deposition and continues throughout subsequent sea-level oscillations to form landforms of surprising symmetry given the asymmetrical interior dune structure. Thus, they record a strikingly unique modification of a very young limestone ridge into cone-shaped landforms that are similar to those arising from apparently different karst processes elsewhere. Despite the cone shape of the hills on Abaco and their development in soluble carbonate rock, they are primarily a pseudokarst feature.

\section{ACKNOWLEDGEMENTS}

The authors thank the Karst Waters Institute, Total SA, and Mississippi State University for providing the funding that made this study possible; the Bahamian government for providing the research permit; Friends of the Environment, Marsh Harbour, Abaco, for providing logistical support; all of the residents of Abaco Island that made this study possible, particularly Nancy and Michael Albury, Anita Knowles, Allison Ball, Diane Claridge, and David Knowles. Brenda Kirkland and Grady Dixon of Mississippi State University, Tony Waltham, and an anonymous reviewer, are thanked for all of their insights and comments during the development of this manuscript. Photo in Figure 2 provided by Nancy Albury.

\section{REFERENCES}

Caputo, M.V., 1995, Sedimentary architecture of Pleistocene eolian calcarenites, San Salvador Island, Bahamas, in Curran, H.A., and White, B., eds., Geological Society of America Special Paper 300, Terrestrial and Shallow Marine Geology of the Bahamas and Bermuda, p. 63-76.

Carew, J.L., and Mylroie, J.E., 1995, Quaternary Tectonic Stability of the Bahamian Archipelago: Evidence from Fossil Coral Reefs and Flank Margin Caves: Quaternary Science Reviews, v. 14, p. 145-153.

Carew, J.L., and Mylroie, J.E., 1997, Geology of the Bahamas, in Vacher, H.L., and Quinn, T.M., eds., Geology and Hydrogeology of Carbonate Islands. Developments in Sedimentology 54, Amsterdam, Elsevier, p. 91-139.

Carew, J.L., and Mylroie, J.E., 2001, Quaternary Carbonate Eolianites of the Bahamas: Useful analogues for the interpretation of ancient rocks?, in Abegg, F.E., Harris, P.M., and Loope, D.B., eds., Modern and Ancient Carbonate Eolianites: Sedimentology, Sequence Stratigraphy, and Diagenesis. SEPM Special Publication No. 71, p. 33-45.

Choquette, P.W., and Pray, L.C., 1970, Geologic Nomenclature and Classification of Porosity in Sedimentary Carbonates: American Association of Petroleum Geologists Bulletin, v. 54, p. 207-250.

Curran, H.A., and White, B., 2001, Ichnology of Holocene carbonate eolianites of the Bahamas, in Abegg, F.E., Harris, P.M., and Loope, D.B., eds., Modern and Ancient Carbonate Eolianites: Sedimentology, Sequence Stratigraphy, and Diagenesis. SEPM Special Publication No. 71, p. 33-45.

Day, M.J., 2004, Cone Karst, in Gunn, J., ed., Encyclopedia of Cave and Karst Science, London, Fitzroy Dearborn Publishers, p. 241-243.

Department of Lands and Surveys, 1975, Topographic map of Abaco, Bahamas. Sheet 20. Nassau, New Providence, Bahamas.

Ford, D.C., and Williams, P.W., 1989, Karst Geomorphology and Hydrology, London, Chapman and Hall, 601 p.

Ford, D.C., and Williams, P.W., 2007, Karst Hydrogeology and Geomorphology, West Sussex, John Wiley \& Sons Ltd., 562 p.

Gillieson, D.G., 1996, Caves: Processes, Development and Management, Oxford, Blackwell Publishers Ltd., 324 p. 
Harris, J.G., Mylroie, J.E., and Carew, J.L., 1995, Banana holes: Unique karst features of the Bahamas: Carbonates and Evaporites, v. 10, p. $215-224$

Haryono, E., and Day, M., 2004, Landform differentiation within the Gunung Kidul Kegelkarst, Java, Indonesia: Journal of Cave and Karst Studies, v. 66, p. 62-69.

Jakucs, L., 1977, Morphogenetics of Karst Regions, New York, John Wiley and Sons, $284 \mathrm{p}$.

Jennings, J.N., 1985, Karst Geomorphology. $2^{\text {nd }}$ ed., Oxford, Basil Blackwell, $293 \mathrm{p}$.

Lehmann, H., 1936, Morphological Studies in Java, Stuggart, Engelhorn, $114 \mathrm{p}$.

Loucks, R.G., and Ward, W.C., 2001, Eolian stratification and beach-todune transition in a Holocene carbonate eolianites complex, Isla Cancũn, Quintana Roo, Mexico, in Abegg, F.E., Harris, P.M., and Loope, D.B., eds., Modern and Ancient Carbonate Eolianites: Sedimentology, Sequence Stratigraphy, and Diagenesis. SEPM Special Publication No. 71, p. 57-76.

Marker, M.E., 1970, Some problems of a karst area of the eastern Transvaal, South Africa: Transactions of the Institute of British Geographers, v. 50, p. 73-85.

Mylroie, J.E., and Carew, J.L., 1995, Chapter 3, Karst Development on Carbonate Islands, in Budd, D.A., Harris, P.M., and Saller, A.H., eds., Unconformities and Porosity in Carbonate Strata, American Association of Petroleum Geologists Memoir 63, p. 55-76.

Mylroie, J.E., Carew, J.L., and Vacher, H.L., 1995, Karst development in the Bahamas and Bermuda, in Curran, H.A., and White, B., eds., Geological Society of America Special Paper 300, Terrestrial and Shallow Marine Geology of the Bahamas and Bermuda, p. 251-267.

Mylroie, J.E., and Mylroie, J.R., 2009, Flank margin cave development as syndepositional caves: Examples from The Bahamas, in White, W.B., ed., Proceedings of the $15^{\text {th }}$ International Congress of Speleology Huntsville, Alabama, National Speleological Society, v. 2, p. 533-539.

O'Brien, J.J., 2006, Direct and Indirect Effects of Fire on the Ecology of Bahamian Pineyards. [Abstract]. In: 2nd Abaco science alliance conference. Marsh Harbour, Abaco, Bahamas: [not paged].

Sweeting, M.M., 1973, Karst Landforms, New York, Columbia University Press, $362 \mathrm{p}$.

Tang, T., and Day, M.J., 2000, Field survey and analysis of hillslopes on tower karst in Guilin, southern China: Earth Surface Processes and Landforms, v. 25, p. 1221-1235.
Trudgill, S., 1985, Limestone Geomorphology. Geomorphology Texts Volume 8, New York, Longman, 196 p.

Tucker, M.E., and Wright, P.W., 1990, Carbonate Sedimentology, Oxford, Blackwell Scientific Publications, $482 \mathrm{p}$.

Vacher, H.L., and Mylroie, J.E., 2002, Eogenetic karst from the perspective of an equivalent porous medium: Carbonates and Evaporites, v. 17, p. 182-196.

Versey, H.R., 1972, Karst of Jamaica, in Herak, M., and Stringfield, V.T., eds., Karst: Important Karst Regions of the Northern Hemisphere, Amsterdam, Elsevier, p. 445-466.

Walker, L.N., 2006, The caves, karst, and geology of Abaco Island, Bahamas. MSc thesis, Mississippi State University, 241 p. http://sun. library.msstate.edu/ETD-db/theses/available/etd-03292006-153441/

Walker, L.N., Mylroie, J.E., Walker, A.D., and Mylroie, J.R., 2008a, A preliminary geologic reconnaissance of Abaco Island, Bahamas, in Freile, D., and Park, L., eds., Proceedings of the $13^{\text {th }}$ Symposium on the Geology of the Bahamas and Other Carbonate Regions, San Salvador, Bahamas, Gerace Research Centre, p. 89-97.

Walker, L.N., Mylroie, J.E., Walker, A.D., and Mylroie, J.R., 2008b, The caves of Abaco Island, Bahamas: Keys to Geologic Timelines: Journal of Cave and Karst Studies, v. 70, p. 108-119.

Whitaker, F.F., and Smart, P.L., 1997, Chapter 4, Hydrogeology of the Bahamian Archipelago, in Vacher, H.L., and Quinn, T., eds., Geology and Hydrogeology of Carbonate Islands, Amsterdam, Elsevier, Developments in Sedimentology 54, p. 183-216.

White, B., and Curran, H.A., 1985, The Holocene carbonate eolianites of North Point and the modern marine environments between North Point and Cut Cay, in Curran, H.A., ed., Pleistocene and Holocene Carbonate Environments on San Salvador Island, BahamasGuidebook for Geological Society of America, Orlando annual meeting field trip, p. 73-93.

White, W.B., 1988, Geomorphology and Hydrology of Karst Terrains, New York, Oxford University Press, 464 p.

White, W.B., 1990, Surface and Near-Surface Karst Landforms, in Higgins, C.G., and Coates, D.R., eds., Groundwater Geomorphology: The Role of Subsurface Water in Earth-Surface Processes and Landforms. Geological Society of America Special Paper 252, Boulder, Colorado, Geological Society of America, p. 157-175.

Williams, P.W., 1972, Morphometric analysis of polygonal karst in New Guinea: Geological Society of America Bulletin, v. 83, p. 761-796. 